\title{
OFFSET PODSTAWA DO UTWORZENIA NOWYCH RELACJI WSPÓŁDZIAŁANIA PRZEDSIĘBIORCÓW O SZCZEGÓLNYM ZNACZENIU GOSPODARCZO-OBRONNYM
}

\begin{abstract}
Dobrze rozumiane współdziałanie między podmiotami, takimi jak przyszła Agencja ds. Inwestycji Obronnych, a administracją rządową może być postrzegane jako korzystne działanie dla dobra rozwoju inwestycji obronnych w kraju. Offset jest integralną częścią współpracy międzynarodowej. Dlatego też istotnym zagadnieniem wydaje się dalsze poszerzanie zagranicznej współpracy polskiego przemysłu obronnego. Offset przyczynia się do wspierania misji sektora obronnego poprzez aktywne uczestnictwo przedsiębiorców w targach i przetargach międzynarodowych, zawieranie bilateralnych umów o współpracy przemysłów obronnych z wybranymi państwami, współpracę przedsiębiorców w ramach Unii Europejskiej i w ramach NATO. Zgodnie z zamiarem dalszego rozwoju rynku wewnętrznego UE i z podejmowaniem starań wyrównywania szans w zakresie dostaw państwa unijne z Europy Środkowo-Wschodniej powinny dokładać wszelkich wysiłków na rzecz wspierania praktyk offsetowych. W szczególności taka sytuacja powinna mobilizować przedstawicieli środowiska polityki do wspierania offsetu. Wymagania offsetowe powinny nam pozwolić na zmniejszenia istniejącej, dużej różnicy rozwojowej pomiędzy bogatymi i biednymi państwami UE. Dlatego też offset powinien być częścią wewnętrznego rynku UE, wzmacniając tym samym sektor obronności. Podtrzymując i rozwijając offsetowe zdolności w celu realizacji bieżących i przyszłych wyzwań bez względu na surowe budżetowe ograniczenia, stałyby się one tylko możliwe przy wdrożeniu polskich reform strukturalnych. To znaczy, że należy podjąć decyzję dotyczącą stworzenia systemu agencyjnego i zapoczątkowania tego zamierzenia poprzez utworzenie Agencji ds. Inwestycji Obronnych. W ten sposób można zbudować nowy fundament dla rozwoju cywilno-wojskowej współpracy.

Słowa kluczowe: offset, Agencja ds. Inwestycji Obronnych, administracja rządowa, inwestycje obronne, współpraca cywilno-wojskowa, ograniczenia budżetowe
\end{abstract}

\section{WPROWADZENIE}

Proponowane rozwiązanie w postaci utworzenia nowej Agencji ds. Inwestycji Obronnych $(\mathrm{AIO})^{3}$ niesie za sobą konieczność podjęcia w ramach administracji rządowej

\footnotetext{
${ }^{1}$ Tomasz Nalepa, dr inż., Niezależny ekspert, ul. Sympatyczna 8/2, 35-14 Rzeszów, Polska, tel. +48 6016640 48, e-mail: , autor korespondencyjny

${ }^{2}$ Bogdan Wójtowicz, dr, Ministerstwo Gospodarki, Departament Programów Offsetowych, Plac Trzech Krzyży 3/5, 00-507 Warszawa, Polska

${ }^{3}$ Zob. B. Wójtowicz, T. Nalepa, Nowoczesne zarzadzanie obronnymi inwestycjami sojuszniczymi i Unii Europejskiej, „Wiedza Obronna (Kwartalnik TWO)” 244/1 (2013), s. 45-70.
} 
współdziałania na rzecz podnoszenia poziomu bezpieczeństwa i obronności państwa ${ }^{4}$ opartego na nowych zasadach. Idea ta stanowi dodatkowy impuls jakościowy, ponieważ nowa agencja nie będzie miała charakteru agencji rządowej.

Instrumentem mającym decydujący wpływ na rozwój technologii, jak również na zmianę jakości produkowanych wyrobów w czasie „P” jest offset. Właściwe przygotowanie umów okołooffsetowych ${ }^{5}$ wraz z przemyślaną ich lokalizacją u polskich przedsiębiorców o szczególnym znaczeniu gospodarczo-obronnym ${ }^{6}$ jest szansą na rozwój narodowego przemysłu zbrojeniowego w pewnych aspektach, jak również będzie powodem nawiązania współdziałania spółek w celu wypracowania właściwych stosunków partnerskich przy wspólnej produkcji wybranych wyrobów, jakie mogą znaleźć się w katalogu ujętym w programie mobilizacji gospodarki (PMG). Istnieje również możliwość wykorzystania tych wyrobów w ramach programów: Program Inwestycji NATO w Dziedzinie Bezpieczeństwa (NATO Security Investment Programme - NSIP ${ }^{7}$ ) czy Wsparcie przez Państwo-Gospodarza (Host Nation Support - HNS ${ }^{8}$ ).

Niedawno została podjęta decyzja dotycząca zlokalizowania departamentu offsetowego. Ostatecznie ta jednostka organizacyjna będzie funkcjonowała pod auspicjami Ministerstwa Obrony Narodowej (MON) ${ }^{9}$. Autorzy zasugerowali już wcześniej alternatywne rozwiązanie, a mianowicie umieszczenie struktur departamentu

${ }^{4}$ Szerzej B. Wójtowicz, T. Nalepa, Wspótdziałanie Agencji ds. Inwestycji Obronnych z administracją rządowa na rzecz rozwoju inwestycji na terytorium Rzeczypospolitej Polskiej, „Wiedza Obronna (Kwartalnik TWO)” 248/1 (2014), s. 62-72.

${ }^{5}$ Zob. T. Nalepa, C. Sochala, Wsparcie rozwoju przemystowego potencjału obronnego, „Przegląd Morski” 52/10 (2011), s. 4-11.

${ }^{6}$ Przedsiębiorca o szczególnym znaczeniu gospodarczo-obronnym to przedsiębiorca realizujący zadania, o których mowa w art. 2 ustawy z dnia 23 sierpnia 2001 r. o organizacji zadań na rzecz obronności państwa realizowanych przez przedsiębiorców, którego terenem działania jest obszar większy niż jedno województwo lub którego przedmiotem wykonywanej działalności gospodarczej jest: 1) eksploatacja lotnisk i portów morskich, 2) kolportaż, 3) nadawanie programów radiowych i telewizyjnych, 4) produkcja, transport i magazynowanie produktów naftowych, 5) produkcja, remont lub modernizacja uzbrojenia i sprzętu wojskowego, 6) realizacja obrotu specjalnego, 7) transport, 8) usługi pocztowe, 9) usługi telekomunikacyjne, 10) wytwarzanie, dystrybucja i przesyłanie gazu ziemnego, paliw płynnych oraz energii elektrycznej. Zob. ustawa z dnia 23 sierpnia $2001 \mathrm{r}$. o organizacji zadań na rzecz obronności państwa realizowanych przez przedsiębiorców (DzU nr 122, poz. 1320).

${ }^{7}$ Szerz. C. Sochala, D. Mientkiewicz, B. Wójtowicz, T. Nalepa, Możliwości finansowego wsparcia rozwoju PPO. Cz. II Działania doraźne: NSIP, HNS, offset, projekty badawcze, „Kwartalnik Bellona” 668/1 (2012), s. 206-220.

${ }^{8}$ Zob. B. Wójtowicz, C. Sochala, T. Nalepa, Realizacja przez przedsiębiorców przemystowego potencjału obronnego zadań w zakresie wsparcia państwa-gospodarza oraz na rzecz mobilizacji gospodarki - w nowych uwarunkowaniach bezpieczeństwa. Propozycja nowych rozwiazań systemowych, „Biuletyn Informacyjny (Kwartalnik TWO ZO Bydgoszcz)" 15/2 (2010), s. 14-25.

${ }^{9}$ Decyzja Nr 70/MON Ministra Obrony Narodowej z dnia 13 marca 2015 r. w sprawie kierowania Ministerstwem Obrony Narodowej (DzU MON Warszawa dnia, 16 marca 2015 r. poz.67):

„2. Ministerstwem Obrony Narodowej kieruje Minister Obrony Narodowej, z zastrzeżeniem pkt 1, za pośrednictwem osób zajmujących kierownicze stanowiska Ministerstwa Obrony Narodowej, z przyporządkowaniem następujących komórek organizacyjnych:

1) Sekretarzowi Stanu w Ministerstwie Obrony Narodowej:

a) Departament Nauki i Szkolnictwa Wojskowego,

b) Departament Polityki Zbrojeniowej,

c) Biuro do Spraw Umów Offsetowych". 
offsetowego z Ministerstwa Gospodarki i nowo utworzonego Zespołu Implementacji Technologii Obronnych w Ministerstwie Obrony Narodowej w ramach proponowanej AIO. Takie podejście niweluje napięcia w administracji rządowej, a jednocześnie usprawnia system agencyjny, który wymaga jednolitej polityki i spójności w taki sposób, by rezultaty przyszłych działań były efektywne i przynosiły określone korzyści dla przemysłowego potencjału obronnego (PPO) ${ }^{10}$.

Rozpatrując wykorzystanie programów NSIP czy HNS, należy zaznaczyć szczególną sytuację polskich stoczni w kontekście poprawy ekonomicznego wykorzystania dostępu Polski do morza, który zobowiązuje również do zwiększenia bezpieczeństwa państwa. Są to więc żywotne interesy narodowe ${ }^{11}$. Równocześnie w wypadku stoczni i innych podmiotów PPO ważnym instrumentem ich rozwoju jawi się offset.

\section{NOWE RELACJE}

Przykładem właściwego wykorzystania offsetu są podpisane umowy na dostawę, montaż i integrację Zintegrowanego Systemu Walki (ZSW) dla okrętu patrolowego typu Ślązak oraz dostawę Zintegrowanego Systemu Łączności (ZSŁ) przez Podsekretarza Stanu w Ministerstwie Gospodarki (MG) - Dariusza Bogdana - w imieniu Skarbu Państwa RP z Thales Nederland B.V. oraz Thales Electronic Systems GmbH 12 grudnia 2013 r.

Umowa offsetowa zawarta $\mathrm{z}$ Thales Nederland B.V. pozwala polskim podmiotom: PBP Enamor Sp. z o.o., OBR CTM S.A. i 1 Regionalnej Bazie Logistycznej na prowadzenie serwisowania i napraw ZSW na poziomie OLM/ILM (włącznie). Natomiast czwarty offsetobiorca - Centrum Wsparcia Teleinformatycznego i Dowodzenia Marynarki Wojennej - uzyska możliwość przeprowadzenia szkoleń operatorskich dla załóg okrętu typu Ślązak obsługujących ZSW.

Natomiast umowa offsetowa $\mathrm{z}$ niemiecką spółką Thales Electronic Systems GmbH dotyczy dostawy ZSŁ dla okrętu patrolowego. Beneficjentami są dwa podmioty: PBP Enamor Sp. z o.o. oraz 1 Regionalna Baza Logistyczna, które będą upoważnione do serwisowania i napraw oraz utrzymania w gotowości sieci Focon docelowo montowanej na pokładzie okrętu typu Ślązak.

Aktualnie w związku z funkcjonowaniem w Siłach Zbrojnych RP dużej liczby morskich jednostek bojowych już wyeksploatowanych i nieodgrywających priorytetowej roli w potencjale bojowym Marynarki Wojennej RP, niezbędne jest rozpoczęcie wypełniania luki w zakresie wprowadzania do uzbrojenia nowych okrętów. Te umowy offsetowe dają niejako ,zielone światło" dla zainicjowania procesu modernizacji polskich sił morskich, które w ostatnim ćwierćwieczu uległy technologicznej degradacji. Mając na uwadze duże znaczenie Marynarki Wojennej RP w krajowym systemie obronnym, należy podejmować wreszcie skuteczne przedsięwzięcia w jej ratowaniu przed dalszą zapaścią.

Realizacja stosownych zobowiązań offsetowych w ramach obu zawartych umów będzie sprzyjała rozwojowi konkurencyjnej bazy przemysłowej w naszym kraju, w związku z czym przyczyni się do rozwoju Europejskiej Bazy TechnologicznoPrzemysłowej sektora obronnego. Argument ten wpisuje się w promowaną przez

\footnotetext{
${ }^{10}$ Szerzej B. Wójtowicz, T. Nalepa, Wizja udoskonalenia implementacji inwestycji obronnych na terytorium RP, „Kwartalnik Bellona” 677/2 (2014), s. 188-200.

${ }^{11}$ Szerzej W. Kustra, Dostęp do morza zobowiązuje, „Przegląd Sił Zbrojnych” 2014/1, s. 28-30.
} 
instytucje wspólnotowe oraz Europejską Agencję Obrony koncepcję stworzenia wspólnego i konkurencyjnego w skali globalnej europejskiego rynku wyposażenia obronnego (European Defence Equipment Market) ${ }^{12}$.

Analiza zdolności operacyjnych ukierunkowana na wskazanie technologii, której rozwój i transfer jest niezbędny do zapewnienia podstawowych interesów bezpieczeństwa państwa w aspekcie potrzeb użytkowników końcowych, uprawnia do stwierdzenia, że osiągniecie tych celów nie jest możliwe przy zastosowaniu rozwiązań innych niż offset. W związku z tym możliwością na pozyskanie technologii jest ich transfer w ramach zobowiązań offsetowych. Jest to jak najbardziej właściwe działanie, by utrzymać odpowiednie zdolności obronne państwa. Mimo wielu zagrożeń powinniśmy dbać o krajowy postęp technologiczny, wykorzystując wszystkie sprzyjające temu środki i mechanizmy.

W czasie globalizacji wolny rynek funkcjonuje w większości państw świata. Jednakże istnieją branże, nawet $\mathrm{w}$ państwach $\mathrm{z}$ liberalną polityką gospodarczą, które podlegają pewnym regulacjom i ograniczeniom. Niewątpliwie do sektora tych branż należy przemysł obronny. Charakterystyczne jest to, że ma on ograniczoną liczbę zainteresowanych podmiotów. Władze państwowe dbają w różnych formach o swój rynek obronny - jedną z nich jest offset ${ }^{13}$. Dlatego też należy dostrzegać jego ważną rolę w tworzeniu pozytywnych relacji wewnątrz i na zewnątrz danego państwa. Rzeczpospolita Polska kładzie szczególny nacisk na utrzymanie krajowego sektora obronnego, mając świadomość, że stanowi on jeden $\mathrm{z}$ ważniejszych wyznaczników suwerenności państwa i utrzymywania pewnego stopnia gotowości mobilizacyjnej ${ }^{14}$. Pojawia się również potrzeba utrzymywania samowystarczalności poszczególnych usług i zapewniania stałych dostaw dla Sił Zbrojnych RP. Ponadto prowadzenie prac badawczorozwojowych $(B+R)$ powinno być stale doskonalone tak, by mogły one sprostać zapotrzebowaniu obronnemu państwa. Krajowy sektor obronny nie może obecnie podołać tym wyzwaniom. Zatem taka sytuacja wymusza podjęcie przez rząd stosownych alternatywnych działań, mogących wypełnić powstałą lukę, która od dawna istnieje w krajowym przemyśle obronnym. Trzeba zdawać sobie sprawę $\mathrm{z}$ tego, że rząd podejmując decyzję dotyczącą zakupów uzbrojenia i sprzętu wojskowego (UiSW) od zagranicznych podmiotów gospodarczych, pozbawia krajowych przedsiębiorców zysku, który by otrzymali w efekcie realizacji danych zamówień.

\footnotetext{
${ }^{12}$ Polska od 2006 r. uczestniczy w procesie wspólnego rynku obronnego w ramach UE zgodnie z decyzją Rady Ministrów w sprawie przystąpienia do Międzynarodowego reżimu stymulującego konkurencyjność Europejskiego Rynku Obronnego. Zob. C. Sochala, P. Ligenza, D. Mientkiewicz, J. Szymanowski, T. Nalepa, Wyzwania $i$ zagrożenia dotyczace systemu rezerw strategicznych oraz przemystowego potencjału obronnego $w$ Polsce. Dylematy Administrowania, AON, Warszawa 2010.

${ }^{13}$ Autorzy zwracają uwagę na właściwość sporządzanych umów offsetowych, z których wynikają bezpośrednie skutki transferu lub nie nowych technologii do PPO. Zakup samolotu bojowego t. F-16 był polityczną ceną, jaką Polska zapłaciła za możliwość „,ochrony parasolem NATO-wskim”. Dziś można uważać, że to zbyt duża cena za sprzęt z wycofywanej 5 Armii Polowej Stanów Zjednoczonych stacjonującej w RFN. Raczej należało wybrać samolot bojowy nowej generacji pochodzący z europejskich programów obronnych.

${ }^{14}$ Zdaniem autorów zamówienia powinny rozkładać się proporcjonalnie do możliwości przedsiębiorców, w tym do przedsiębiorców z niepaństwowego sektora przemysłu obronnego (np. TELDA, WB Electronics S.A.). Brak właściwego zrozumienia w stawianych zadaniach dla podmiotów przez decydentów w ramach Programu Mobilizacji Gospodarki może prowadzić do niewłaściwego zabezpieczenia resortów kluczowych RP oraz niepełnego wykorzystania możliwości PPO w tym zakresie.
} 
Stąd offset stanowi kluczowe narzędzie dla tych gospodarek, które nie są w pełni wystarczalne w sektorze obronnym. Offset jest instrumentem wykorzystywanym przez państwa członkowskie Unii Europejskiej (UE), chociaż staje się dziś mechanizmem kontrowersyjnym. Ale czy słusznie? Offset przecież pozwala na stopniowe doganianie państw znacznie bardziej zaawansowanych technologicznie dzięki możliwości rozwoju bazy naukowo-badawczej w postaci transferu nowych technologii ${ }^{15}$.

Sprawy bezpieczeństwa w ramach resortu gospodarki skupiają się obecnie na realizacji funkcji bezpieczeństwa gospodarczego. Należy jednak dostrzec, że złożoność oraz dynamiczne zmiany zachodzące w środowisku bezpieczeństwa wymuszają refleksję nad integralnością i efektywnością systemu zarządzania kryzysowego jako jednego z głównych elementów systemu bezpieczeństwa narodowego ${ }^{16}$.

Bezpieczeństwo gospodarcze kraju stanowi jeden z sześciu priorytetów strategicznych działalności Ministerstwa Gospodarki. W zakresie zapewnienia bezpieczeństwa gospodarczego kraju resort gospodarki wykonuje zadania zmierzające do:

- dywersyfikacji źródeł i kierunków dostaw nośników energii oraz rozbudowy infrastruktury sieciowej kraju;

- $\quad$ poprawy efektywności energetycznej, w jej ramach prowadzone działania obejmują trzy obszary: zmniejszenie zużycia energii, podwyższenie sprawności jej wytwarzania oraz ograniczenie strat energii w przemyśle i dystrybucji;

- $\quad$ wzrostu wykorzystania energii ze źródeł odnawialnych, w tym biopaliw ciekłych;

- zaspokojenia krajowego zapotrzebowania na węgiel kamienny poprzez wzrost efektywności funkcjonowania górnictwa węgla kamiennego;

- budowy infrastruktury dla energetyki jądrowej (planowane jest wprowadzenie energetyki jądrowej w kraju od 2021 r.);

- $\quad$ zapewnienia potrzeb obronnych w zakresie przygotowania gospodarki do funkcjonowania w warunkach zagrożenia bezpieczeństwa i w czasie wojny;

- zapewnienia bezpieczeństwa międzynarodowego łańcucha dostaw towarów o znaczeniu strategicznym i skutecznej kontroli obrotu towarami wytwarzanymi w kraju oraz importowanymi.

Podejmowany wysiłek na rzecz zapewnienia potrzeb obronnych państwa oraz skuteczna kontrola dostaw towarów o znaczeniu strategicznym wpisują się w formę, jaką jest offset. Narzędzie to stanowić będzie nadal źródło pozyskania nowych technologii i produktów, jak również będzie nakładało na offsetobiorcę obowiązek rzetelnej ochrony praw związanych z patentami, technologiami i dystrybucją wytworzonych produktów w ramach kontraktów biznesowych. Nowe podejście do zagadnienia offsetu wymaga dalszych zmian prawnych w polskim ustawodawstwie, które muszą być zgodne z unijnym. W konsekwencji należy pamiętać o tym, że szczególnie rosnąca dynamika zmian otoczenia powoduje niebywały wzrost zainteresowania koncepcjami, metodami i technikami zarządzania, pozwalającymi radzić sobie z coraz większą niepewnością

\footnotetext{
${ }^{15}$ Autorzy uważają, że specjaliści opracowujący umowy offsetowe są odpowiedzialni za ich właściwy charakter - zarówno pod względem ewentualnego transferu nowych technologii, jak i innych zasadniczych kwestii w dziedzinie bezpieczeństwa narodowego. W konsekwencji powinni oni posiadać stosowne kwalifikacje. Z doświadczeń wynika, że oprócz wiedzy ekonomicznej i prawniczej - niezbędna okazuje się w ich wypadku poszerzona wiedza nabyta w ramach Wyższych Kursów Obronnych w AON.

${ }^{16}$ G. Sobolewski, Zagrożenia kryzysowe, AON, Warszawa 2011, s. 9.
} 
dotyczącą środowiska, w którym działają organizacje. Naprzeciw tym potrzebom wychodzi koncepcja zarządzania strategicznego, która na przestrzeni niemal 50 lat ewoluowała od sztywnego, racjonalistyczno-planistycznego podejścia do obecnie coraz bardziej popularnego - kompetencyjnego, pozwalającego myśleć i działać strategicznie nawet najmniejszym organizacjom ${ }^{17}$.

\section{UNIJNE ZOBOWIĄZANIA}

Mając na uwadze konieczność stworzenia nowych relacji współdziałania, należałoby pokusić się o próbę uzdrowienia podejścia do problematyki offsetowej. Powinna temu służyć nowelizacja ustawy offsetowej ${ }^{18}$ - przyjęta przez Radę Ministrów w lutym 2014 r. Trzeba mieć przy tym na uwadze rangę zadań realizowanych przez krajowych urzędników państwowych. Często mówi się o konieczności redukcji ich liczby, zazwyczaj zapominając o na przykład konieczności ich stosownego przygotowania do pracy. To zaniedbanie $\mathrm{z}$ kolei pociąga za sobą ogromne koszty. Do nich przecież należy wypracowywanie kluczowych decyzji w różnych płaszczyznach administrowania państwem, co nie stanowi przedmiotu działalności UE. Wręcz przeciwnie, administracja unijna wprowadza właśnie warunkowe programowanie, co zawsze oznacza istnienie alternatywy. Wprawdzie są unijne dyrektywy, ale wbrew pozorom istnieje tu bardzo duża swoboda. Dla Unii efektywne zarządzanie na poziomie państw jest kluczową sprawą ${ }^{19}$.

Trzeba mieć jednak świadomość istniejących regulacji prawnych UE co do offsetu. Zamówienia związane bezpośrednio z dziedziną obronności są znaczącą częścią składową zamówień publicznych UE. Należy podkreślić, że europejski sektor obronny jest zbyt rozproszony na szczeblu krajowym. Taka sytuacja stanowi ogromną przeszkodę w rozwoju współpracy i konkurencji na rynku wewnętrznym Unii. Prawo zamówień publicznych jest jednym z głównych czynników wpływających na to rozproszenie. Offset jest współcześnie instrumentem szeroko stosowanym w skali globalnej. Również państwa UE oraz Organizacji Paktu Północnoatlantyckiego (NATO) - Hiszpania, Norwegia korzystają $\mathrm{z}$ offsetu jako korzystnego rozwiązania o znaczącym wpływie na bezpieczeństwo narodowe. Chociaż praktyki offsetowe poszczególnych państw UE nadal oparte są na odmiennych zasadach i regulacjach prawnych i nie są jeszcze w pełni jednolicie wdrożone - występują w różnej formie oraz posługują się odmiennym nazewnictwem, to koncepcja jego zastosowania ma tę samą ideę, tzn. offset w ramach Europejskiej Bazy Technologiczno-Przemysłowej (EDTIB, European Defence Technological and Industrial Base) ma zagwarantować równowagę między rozwojem bazy a potrzebą uzyskiwania równych szans na europejskim oraz na globalnym rynku obronnym.

Aktualnie w UE można dostrzec odmienne podejścia tej organizacji oraz jej członków - w aspekcie zgodności stosowania offsetu w państwach członkowskich z prawem unijnym. Traktat o Funkcjonowaniu Unii Europejskiej (TFUE) wyznacza podstawowe ramy prawne obowiązujące $w$ UE. Został on opracowany $z$ myślą budowy wspólnej polityki handlowej przez stopniowe usuwanie ograniczeń istniejących $\mathrm{w}$ handlu

\footnotetext{
${ }^{17}$ P. Daniluk, Zarządzanie strategiczne. Analiza strategiczna organizacji, AON, Warszawa 2008, s. 5.

${ }^{18}$ http://www.mg.gov.pl/node/19989 (dostęp: 20.02.2014).

${ }^{19}$ J. Staniszkis, Szanse dla Polski. Nasze możliwości rozwoju w obecnym świecie, Rectus, Warszawa 2005, s. 23.
} 
międzynarodowym. Dla możliwości zastosowania instrumentu, jakim jest offset, decydujący jest artykuł 346 TFUE (dawniej artykuł 296 TWE). W ust. 1 lit. b) zapisano, że: „każde Państwo Członkowskie może podejmować środki, jakie uważa za konieczne w celu ochrony podstawowych interesów jego bezpieczeństwa, a które odnoszą się do produkcji lub handlu bronią, amunicją lub materiałami wojennymi; środki takie nie mogą negatywnie wpływać na warunki konkurencji na wspólnym rynku w odniesieniu do produktów, które nie są przeznaczone wyłącznie do celów wojskowych".

$\mathrm{Na}$ świecie kwestia offsetu jest różnie regulowana. W Polsce przyjęto rozwiązanie ustawowe zgodnie z art. 22 Konstytucji RP, który stanowi: „Ograniczenie wolności działalności gospodarczej jest dopuszczalne tylko w drodze ustawy i tylko ze względu na ważny interes publiczny".

Parlament Europejski i Rada 13 lipca 2009 r. przyjęły Dyrektywę 2009/81/WE w sprawie udzielania zamówień w dziedzinach obronności i bezpieczeństwa (tzw. Dyrektywa Obronna). Stanowi ona instrument prawny mający na celu zagwarantowanie przestrzegania podstawowych przepisów Traktatu w tak ważnej dziedzinie, jaką jest bezpieczeństwo i obronność. Zadaniem dyrektywy stało się doprowadzenie do realizacji zamówień w dziedzinie obronności, podlegających zasadom wolnej konkurencji, wprowadzenie procesu liberalizacji rynku obronnego.

Stworzenie sprawnie i płynnie funkcjonującego europejskiego rynku zamówień obronnych było głównym celem Komisji Europejskiej. Wydaje się, że z powodzeniem mogłaby realizować te zadania, na gruncie krajowym, Agencja ds. Inwestycji Obronnych, której powołanie się sugeruje. Z tym zamiarem opracowana Dyrektywa Obronna miała zwiększyć transparentność w zamówieniach, wyeliminować niezgodne z prawem unijnym praktyki handlowe. Ponadto miała zwiększyć konkurencyjność oferentów. Komisja Europejska uważa offset za jeden z środków, z których mogą korzystać państwa członkowskie w celu zapewnienia ochrony fundamentalnych interesów bezpieczeństwa. Podobne stanowisko wyrażone zostało w Rezolucji Parlamentu Europejskiego z 14 grudnia 2011 r. Według punktu 59 Rezolucji ,praktyki offsetowe mogą być jedynie uzasadnione, wtedy gdy są konieczne do zapewnienia podstawowych względów bezpieczeństwa zgodnie $\mathrm{z}$ art. 346 TFUE oraz zgodnie $\mathrm{z}$ zasadami przejrzystości, a w szczególności nie mogą powodować zagrożeń korupcji i zakłóceń w funkcjonowaniu rynku obronnego na obszarze UE".

W celu zagwarantowania prawidłowego stosowania Dyrektywy 2009/81/WE Komisja Europejska wydała stosowne Wytyczne w sprawie offsetu. Aby zastosowanie offsetu było możliwe, państwo członkowskie, które chce skorzystać z powstałej deregulacji, musi każdorazowo uzasadnić, że jest on niezbędny w celu zagwarantowania jego podstawowego założenia. Musi również być zdefiniowany fundamentalny interes bezpieczeństwa będący wyznacznikiem dla zastosowania offsetu. Tutaj autorzy niniejszego artykułu dopatrują się bardzo istotnej roli należącej do ewentualnie sformowanej w kraju Agencji ds. Inwestycji Obronnych, ponieważ prezentowałaby ona sprecyzowane i jednolite narodowe stanowisko w tej kwestii. Stosowanie offsetu musi zostać uzasadnione w specjalnym trybie przez odwołanie się do obowiązku ochrony podstawowych interesów państwowych, tzn. do art. 346 TFUE. Pozwoliłoby to na uniknięcie większych lub mniejszych rozdźwięków między różnymi ogniwami administracji państwowej. Należy podkreślić, że brak spełnienia tego wymogu może skutkować wszczęciem przez Komisję Europejską postępowania przed Trybunałem Sprawiedliwości UE. Nieoczekiwanie offset stał się kontrowersyjny w UE. Można się 
w tym dopatrywać braku pewnej konsekwencji, ponieważ powszechnie uznaje się, że członkostwo w UE otworzyło drogę do rozwoju i modernizacji oraz funkcjonowania w obszarze najbardziej rozwiniętych państw świata. Dlatego dziś nie sposób już analizować zagrożeń z historycznego punktu widzenia, bo dynamika przemian w świecie faktycznie wyeliminowała „stare” zagrożenia. Nie znaczy to oczywiście, że aktualnie nie ma zagrożeń dla bezpieczeństwa Polski, ale mają one już inny wymiar i innego rodzaju skutki mogą powodować ${ }^{20}$.

\section{BYĆ PRZEWIDUJĄCYM}

Działania reorganizacyjne podjęte w MON w zakresie utworzenia nowego ogniwa zajmującego się offsetem, a jednocześnie brak zainteresowania zatrudnieniem ekspertów merytorycznych z Departamentu Programów Offsetowych Ministerstwa Gospodarki jest działaniem szkodliwym, nastawionym na zaspokojenie jedynie własnych ambicji. Trzeba w takich okolicznościach pamiętać o racjonalnym czynniku, jakim jest planowanie, a zasadniczym celem planowania powinno być skoordynowanie działań komórek organizacyjnych danego podmiotu (organizacji, grupy itp.) poprzez określenie szczegółowych zadań, wskazanie ich miejsc, terminów, treści, formy oraz wykonawców, a także wyróżnienie zasadniczych przedsięwzięć, można by rzec zadań strategicznych, których wykonanie będzie przybliżało dany podmiot do osiągnięcia założonego wcześniej celu. Należy przy tym zaznaczyć, że właściwe planowanie, uwzględniające koordynację procesów zachodzących w strukturach danego podmiotu, zapewni jego skuteczne przygotowanie do realizacji wyznaczonych zadań, często nawet przy zmiennych warunkach otoczenia ${ }^{21}$.

Nowy personel bez doświadczeń niezbędnych we wszechstronnej obsłudze umów offsetowych będzie się uczył i prawdopodobnie popełniał różne błędy. Polski nie stać na ponoszenie dodatkowych kosztów kształcenia nowych specjalistów zajmujących się „offsetem”. W tym miejscu przychodzi na myśl zdanie Stefana Korneliusa: „Nie ma prostego rozwiązania takiej sytuacji - to pewne" 22 . Jednakże obecnie procedury offsetowe realizuje nadal Departament Programów Offsetowych Ministerstwa Gospodarki pomimo delegacji ustawowych. Dotyczy to nowego zamierzenia wykonywanego przez MON. Resort ten planuje kupić 70 śmigłowców wielozadaniowych. Offset jest znów cenny i w rzeczywistości to w Ministerstwie Gospodarki kontynuowane są prace przez stosowny Zespół do zbadania ofert offsetowych oraz przeprowadzenia negocjacji w celu zawarcia umowy offsetowej. Trzeba pamiętać, że dopiero po podpisaniu umowy offsetowej możliwe będzie zawarcie umowy dostawy wielozadaniowych śmigłowców. Ministerstwo Obrony Narodowej oczekuje, aby oferowane Siłom Zbrojnym RP śmigłowce miały wszystkie niezbędne pozwolenia i certyfikaty umożliwiające militarną eksploatację. Producenci zapewniają, że ich helikoptery w terminie spełnią wszystkie wymagania. Natomiast resort gospodarki oczekuje, że w wypadku wygranej jednego z oferentów będzie można stwierdzić jego zaangażowanie przemysłowe, które mogłoby wzbogacić polską gospodarkę o inwestycje jednego z trzech największych koncernów

\footnotetext{
${ }^{20}$ M. Adamkiewicz, Interdyscyplinarny wymiar bezpieczeństwa, WAT, Warszawa 2012, s. 52.

${ }^{21}$ W. Kitler, Planowanie cywilne w zarzadzaniu kryzysowym, AON, Warszawa 2011, s. 17.

${ }^{22}$ S. Kornelius, Pani Kanclerz Angela Merkel, wyd. I, FILIA, Termedia, Poznań 2013, s. 237.
} 
helikopterowych na świecie. Sytuacja taka dowodzi, że przeniesienie spraw offsetowych do MON nie było trafnym rozwiązaniem, chociażby z powodu niewykorzystania zasobów offsetowych Ministerstwa Gospodarki, dysponujących doświadczeniem liczącym się w skali kraju. Ponadto oczekiwania w kwestii realizacji offsetu dotyczą nie tylko spraw bezpieczeństwa, ale i spraw gospodarczych. W konsekwencji więc zasoby osobowe MON staną przed koniecznością szybkiego nabycia niezbędnej wiedzy, a do tego przy ponoszeniu przez budżet państwa dodatkowych kosztów.

Analogiczna sytuacja w przeszłości zaistniała w wypadku byłych jednostek organizacyjnych MON (przełom lat 2002/2003), gdy w wyniku nieprzemyślanego działania zwolniono kadrę naukowo-dydaktyczną Wojskowej Akademii Technicznej w Warszawie. W rezultacie tych działań znaczna część jej pracowników naukowych została przejęta przez firmy zagraniczne w kraju i za granicą. Obecnie niepokojące posunięcia stosuje się również w prestiżowej uczelni mającej wieloletnie doświadczenie w kształceniu kadr oficerskich, a mianowicie Akademii Obrony Narodowej (propozycja przeformowania AON na przykład w Uniwersytet Obrony - w ramach planowanej reformy szkolnictwa wojskowego). Należy dostrzegać pewien aspekt sprawy, mówiący, że historia lubi się powtarzać, tym razem jednak dotyczy to wąskiego grona ekspertów Departamentu Programów Offsetowych Ministerstwa Gospodarki. Autorzy podkreślają, że istnieje kompromisowe rozwiązanie, które pozwoli na wyjście z tego impasu. Jest nim propozycja wzmocnienia narodowego systemu instytucjonalnego przez utworzenie wspomnianej AIO, która pozyskałaby pracowników zarówno z Ministerstwa Gospodarki MG, jak i nowo tworzonej komórki organizacyjnej w MON. Rozwiązanie to nie budziłoby niepotrzebnych emocji ani kontrowersji związanych $\mathrm{z}$ budowaniem nowego modelu offsetu w ramach innego ministerstwa ${ }^{23}$.

Jakkolwiek by oceniać znaczenie tego istotnego zagadnienia z punktu widzenia jego skali i skuteczności - a dotychczasowa ocena wdrożenia tego zamierzenia wydaje się trafna - faktem jest, że w ostatniej dekadzie, po wielu latach kontrowersji w tym zakresie, wyeksponowanie ważnej roli nowej AIO jako ogniwa wpływającego pozytywnie na proces kooperacji na najwyższym szczeblu zarządzania i kierowania w tym zakresie skierowanego na realizację i kształtowanie polityki offsetowej.

Nowelizacja ustawy offsetowej powinna być wsparciem dla krajowego przemysłu obronnego. W tej sytuacji nasuwa się pytanie: czy po przejęciu obowiązków wynikających z ustaleń dokonanych przez Radę Ministrów - MON będzie zdolne wesprzeć krajowy przemysł obronny w działaniach offsetowych, nie mając obecnie wypracowanych struktur organizacyjnych i przygotowanego merytorycznie personelu w tej dziedzinie?

Zdobyte dziesięcioletnie, niezwykle cenne doświadczenia w Ministerstwie Gospodarki w dziedzinie stosowania offsetu ${ }^{24}$ mogłyby posłużyć pracom dostosowawczym

\footnotetext{
${ }^{23}$ Zob. B. Wójtowicz, P.P. Nogal, T. Nalepa, Aktualne problemy i działania administracyjne w zakresie funkcjonowania $i$ doskonalenia przemystu obronnego w Polsce, „Modern Management Review (Politechnika Rzeszowska)", XIX/21 (2014), s. 161-177.

${ }^{24}$ Przykładem ilustrującym wpływ zobowiązań offsetowych na PPO jest realizacja programu kołowego transportera opancerzonego (KTO) - „Rosomak” przy współpracy Patria Land \& Armament Oy i Oto Melera S.p.A. Szerzej C. Sochala, P. Ligenza, D. Mientkiewicz, J. Szymanowski, T. Nalepa, Wyzwania i zagrożenia dotyczace systemu rezerw strategicznych oraz przemystowego potencjału obronnego w Polsce. ... op. cit., s. 40-41.
} 
podejmowanym w resorcie obrony narodowej w tym zakresie. Jednakże wymagana jest poprawa dotychczasowej współpracy w obszarze problematyki offsetowej. Wydaje się, że potrzebna jest intensywniejsza współpraca międzyresortowa przy podejmowaniu tego typu wyzwań. Nadal musimy pamiętać o tym, że oczekiwany transfer technologii do krajowych spółek pozwoli na dalszy ich rozwój w taki sposób, by doganiać te państwa unijne, które znajdują się na poziomie bardziej zaawansowanym pod względem technologicznym. W przyszłości, na przykład, polskie okręty będą wyznaczane do Grup Bojowych UE i obecnie nasuwa się pytanie - czy Rzeczpospolita Polska podoła w przyszłości temu zadaniu?

\section{LITERATURA}

[1] Adamkiewicz M., Interdyscyplinarny wymiar bezpieczeństwa, WAT, Warszawa 2012.

[2] Daniluk P., Zarzadzanie strategiczne. Analiza strategiczna organizacji, AON, Warszawa 2008.

[3] Decyzja Nr 70/MON Ministra Obrony Narodowej z dnia 13 marca 2015 r. w sprawie kierowania Ministerstwem Obrony Narodowej (DzU MON Warszawa 16 marca 2015 r. poz. 67).

[4] http://www.mg.gov.pl/node/19989 (dostęp: 20.02.2014).

[5] Kitler W., Planowanie cywilne w zarzadzaniu kryzysowym, AON, Warszawa 2011.

[6] Kornelius S., Pani Kanclerz, Angela Merkel, wyd. I, FILIA, Termedia, Poznań 2013.

[7] Kustra W., Dostęp do morza zobowiazuje, ,Przegląd Sił Zbrojnych” 2014/1, s. 28-30.

[8] Nalepa T., Sochala C., Wsparcie rozwoju przemystowego potencjatu obronnego, „Przegląd Morski" 52/10 (2011), s. 4-11.

[9] Sobolewski G., Zagrożenia kryzysowe, AON, Warszawa 2011.

[10] Sochala C., Ligenza P., Mientkiewicz D., Szymanowski J., Nalepa T., Wyzwania i zagrożenia dotyczace systemu rezerw strategicznych oraz przemystowego potencjatu obronnego w Polsce. Dylematy Administrowania, AON, Warszawa 2010.

[11] Sochala C., Mientkiewicz D., Wójtowicz B., Nalepa T., Możliwości finansowego wsparcia rozwoju PPO, część II: Działania doraźne: NSIP, HNS, offset, projekty badawcze, „Kwartalnik Bellona" 668/1 (2012), s. 206-220.

[12] Staniszkis J., Szanse Polski. Nasze możliwości rozwoju w obecnym świecie, Rectus, Warszawa 2005.

[13] Wójtowicz B., Nalepa T., Wizja udoskonalenia implementacji inwestycji obronnych na terytorium $R P$, „Kwartalnik Bellona” 677/2 (2014), s. 188-200.

[14] Wójtowicz B., Sochala C., Nalepa T., Realizacja przez przedsiębiorców przemystowego potencjału obronnego zadań w zakresie wsparcia państwa-gospodarza oraz na rzecz mobilizacji gospodarki $-w$ nowych uwarunkowaniach bezpieczeństwa. Propozycja nowych rozwiazań systemowych, „Biuletyn Informacyjny (Kwartalnik TWO ZO Bydgoszcz)” 15/2 (2010), s. 14-25.

[15] Wójtowicz B., Nalepa T., Nowoczesne zarządzanie obronnymi inwestycjami sojuszniczymi i Unii Europejskiej, „Wiedza Obronna (Kwartalnik TWO)” 244/1 (2013), s. 45-70.

[16] Wójtowicz B., Nalepa T., Wspótdziałanie Agencji ds. Inwestycji Obronnych zadministracja rzadowa na rzecz rozwoju inwestycji na terytorium Rzeczypospolitej Polskiej, „Wiedza Obronna (Kwartalnik TWO)" 248/1 (2014), s. 62-72.

[17] Wójtowicz B., Nogal P.P., Nalepa T., Aktualne problemy i dziatania administracyjne w zakresie funkcjonowania i doskonalenia przemystu obronnego $w$ Polsce, „Modern Management Review (Politechnika Rzeszowska)”XIX/21 (2014), s. 161-177. 


\section{OFFSET AS A BASE FOR ESTABLISHMENT OF A NEW COOPERATION RELATIONS OF ENTREPRENEURS OF SPECIAL ECONOMIC - DEFENCE SIGNIFICANCE}

We should understand the meaning of cooperation between units. It means a cooperation, for instance, between the future Agency of Defence Investments and the Administration of Government. It should be noticed as a profitable activity for a development of national investments. Offset is an integral part of international cooperation and that's why offset possesses the key issue. It seems that we need further enlargement of cooperation in the sphere of foreign cooperation of the Polish Industrial Defence. We can achieve it by active participation of entrepreneurs in fairs and in international bids, enter into an agreement of cooperation in the sphere of industrial defence, EU and NATO cooperation of entrepreneurs. In order to further develop the Internal Market for defence and work towards a level playing field for all European suppliers, the Eastern and Central member-countries of European Union should make every efforts to support offset practices. It will, in particular, mobilize its policies for support offset. Offset requirements allow us to decrease a gap of development between reach and poor countries of EU. Therefore, offset should be a part of the internal market for defence. Maintaining and developing offset capabilities to meet current and future challenges in spite of severe budget constraints will only be possible if far-reaching Polish structural reforms are made. It means we should take a decision about form a system of agencies and start creating process of the Agency of Defence Investments. In this way we can build a new framework for developing civil - military coo-peration.

Keywords: offset, Agency of Defence Investments, Administration of Government, defence investments, civil-military cooperation, budget constraints

DOI: 10.7862/rz.2015.mmr.40

Tekst złożono w redakcji: kwiecień 2015

Przyjęto do druku: wrzesień 2015 